\title{
REACTIVE STROMA IN PROSTATIC CARCINOMA AND CORRELATION WITH TUMOR GRADE AND TUMOR STAGE
}

\section{РЕАКТИВНА СТРОМА КАЈ ПРОСТАТИЧЕН КАРЦИНОМ И КОРЕЛАЦИЈА СО ГРАДУС И СТАДИУМ НА ТУМОР}

\author{
Vanja Filipovski ${ }^{1}$, Katerina Kubelka-Sabit ${ }^{1}$, Dzengis Jasar ${ }^{1}$, Gligor Dimitrov ${ }^{2}$ and Vesna Janevska ${ }^{3}$
}

${ }^{1}$ Department of Histopathology and Cytology, Clinical Hospital Acibadem-Sistina, Skopje, ${ }^{2}$ Department of Gynecology and Obstetrics, General Hospital Re-Medica, Skopje, ${ }^{3}$ Institute of Pathlogy, University "Ss Cyril and Methodius", Medical Faculty Skopje, Republic of Macedonia

\section{Abstract}

Introduction. Reactive stroma co-evolves with prostatic carcinoma. The aim of this study is to establish stromal changes in the prostatic cancer tissue and to quantify those changes.

Methods. Samples from 70 patients treated with radical prostatectomy due to prostatic cancer were used for this analysis. Stromal changes in prostatic cancer tissue were analyzed using histochemical stain Trichrome Masson and immunohistochemical stains Vimentin and Desmin and those changes were compared to the stromal composition in the surrounding benign prostatic hyperplasia. These changes were quantified as following: for the histochemical stain Trichrome Masson we measured the intensity of the stain and for the immunohistochemical stains Vimentin and Desmin we used the "stromal index" that combines the frequency and intensity of the signal. We correlated the received data between each parameters and with tumor grade and tumor stage using the Spearman rank correlation test.

Results. There was significant correlation between Trichrome Masson staining intensity and tumor grade $(\mathrm{R}=0,27 \mathrm{p}=0,023)$ and tumor stage $(\mathrm{R}=0,24 \mathrm{p}=0,049)$, between Vimentin expression and tumor grade $(\mathrm{R}=0,35$ $\mathrm{p}=0,003)$ and tumor stage $(\mathrm{R}=0,28 \mathrm{p}=0,019)$ and between Desmin expression and tumor grade $(R=-0,25 \mathrm{p}=0,035)$.

Conclusion. Analyses of the stromal composition and the expression of stromal markers in prostatic carcinoma and their quantification could serve as an additional tool in evaluation of tumor aggressiveness and tumor extension.

Keywords: prostatic carcinoma, stroma, immunohistochemistry

Correspondence to: Vanja Filipovski, Department of Histopathology and Cytology, Clinical Hospital Acibadem-Sistina Skopje, "Skupi5a", 1000 Skopje, R. Macedonia; Phone: +389 703849 68; E-mail: v_filipovski@yahoo.com
Апстракт

Вовед. Реактивна строма ко-еволуира со простатичен карцином. Целата на студијата е да се утвдат стромални промени во простатичното канцерско ткиво и да се квантифицираат тие промени.

Методи. За оваа анализа се користеа примероци од 70 пациенти третирани со радикална простатектомија поради простатичен карцином. Стромалните промени кај простатичниот карцином беа анализирани користејќи го хистохемиското боење Trichrome Masson и имунохистохемиските боења: Vimentin и Desmin и овие промени беа споредени со околни подрачја на бенигна простатична хиперплазија. Промените беа квантифицирани на следниов начин: кај хистохемиското боење Trichrome Masson се одреди интензитетот на пребојувањето на стромата додека кај имунохистохемиските боења Vimentin и Desmin се употреби “индекс на пребојување” кој ги комбинира фрефкфенцијата на сигналот со интензитетот на сигналот. Добиените податоци се корелираа меѓусебно и со градус и стадиум на тумор користејќи Spearman-ов тест за корелација.

Резултати. Се покажа сигнификантна корелација помеѓу Trichrome Masson боењето со градусот на туморот $(\mathrm{R}=0,27 \mathrm{p}=0,023)$ и со стадиумот на болеста $(\mathrm{R}=0,24 \mathrm{p}=0,049)$, помеѓу експресијата на антителото Vimentin со градусот на туморот $(\mathrm{R}=0,35 \mathrm{p}=0,003)$ и стадиумот на болеста $(\mathrm{R}=0,28 \mathrm{p}=0,019)$ и помеѓу експресијата на антителото Desmin и градусот на туморот $(\mathrm{R}=-0,25 \mathrm{p}=0,035)$.

Заклучок. Анализи на составот на стромата и експресија на стромални маркери кај простатичен карцином и нивна квантификација може да служи како дополнителна алатка во евалуација на агресивноста и проширеноста на простатичниот карцином.

Клучни зборови: простатичен карцином, строма, имунохистохемија. 


\section{Introduction}

Stroma represents tissue component made up of extracellular matrix components and several cell types: fibroblasts, endothelial cells, smooth muscle cells, macrophages, mast cells and a number of cells that pass through the microenvironment via blood and lymph vessels. Smooth muscle cells predominate in prostatic tissue and they derive from the mesenchyme of urogenital sinus. These cells are the most important cell type regarding prostate development, maintenance and homeostasis. Changes in smooth muscle cells could be important in evolution of prostatic carcinogenesis. The differentiation of prostatic smooth muscle cells occurs in a highly orderly manner with sequential expression of characteristic markers including vimentin, actin, desmin and vinculin. The process of dedifferentiation following castration is associated with rapid regression of prostatic epithelium combined with ordered loss of expression of these markers in opposite direction [1]. Changes occurring in the surrounding connective tissue stroma serve to enhance the malignant potential of the nearby epithelium [2]. Epigenetic influences derived from stromal cells may be crucial in determining whether a tumor will assume slowly growing or invasive phenotype [3-4]. Genetic mutation in the prostatic epithelium could alter the signaling to nearby smooth muscle cells and may trigger stromal dedifferentiation toward fibroblast phenotype. This transformation may yield a change in the local microenvironment, from promotion of epithelial homeostasis, toward epithelial mitogenesis and this may enhance the invasive potential of genetically altered epithelial cells [1]. This altered so called reactive stroma, surrounding epithelial carcinoma cells is not yet fully defined [5]. There are similarities of cancer stroma with the stroma involved in wound repair. A special cell type called myofibroblast is found in sites of pathologic tissue repair. In wound repair, myofibroblasts derive from granulation tissue fibroblasts and in cancer carcinoma cells induce fibroblasts to the reactive myofibroblast phenotype [6]. Authors have suggested the term carcinoma associated fibroblasts for these cells. Some characteristics of these cells are established. They do not form tumors when grown in absence of epithelium, stimulate progression of genetically altered non tumorogenic prostate epithelium toward carcinomatous phenotype, and are unable to stimulate initiation of genetically normal prostatic epithelium $[1,5]$.

\section{Material and Methods}

A retrospective analysis was performed using archive paraffin blocks from 70 consecutive patients that underwent radical prostatectomy due to previously diagnosed prostatic cancer on needle core biopsy. All cases presented with localized disease or locally advanced disease meaning that there were no metastatic deposits in the regional lymph nodes and no distant metastases according to the previous radiology imaging analyses. Adequate samples were chosen that contained almost equal amounts of prostatic cancer tissue and surrounding benign prostatic tissue.

First the sections were stined with Trichrome Masson histochemical stain, following standard procedure. Normal prostatic smooth muscle cells stained red and reactive stroma surrounding prostatic carcinoma stained blue. Under low magnification (x40) an area of most intense blue stain was chosen and then on high magnification (x400) five consecutive areas were analyzed. The amount of reactive stroma was graded semi quantitatively as follows: $0=$ no blue staining; $1=$ weak blue staining; $2=$ moderate blue staining; and $3=$ strong blue staining. Then additional sections were taken for the immunohistochemical analysis of the stroma. For this analysis the following antibodies were used: Vimentin, clone V9, IgG1 class (DAKO), dilution 1:50 and Desmin, clone D33, IgG1 class (DAKO), dilution 1:50. Immunohistochemical staining was performed with the technique of Avidin-Biotin Immunoperoxydase Complex, Using LSAB and En-Vision kit for visualization of the antigen-antibody complex. Immunohistochemically, smooth muscle cells of normal prostatic stroma are Vimentin negative and Desmin positive, while carcinoma associated fibroblasts are Vimentin positive and Desmin negative. In order to determine the intensity of stromal changes in prostatic carcinoma the percentage of stromal cells positive for Vimentin and Desmin the following procedures were taken: First, an area with the most intense blue staining on Trichrome Masson histochemical stain was identified, and then, on high magnification (x400), the same area was analyzed on five consecutive fields. Scoring scale was established for the analysis of frequency of positive cells from 0 to $3: 0=0 \%$ positive stromal cells; $1=1-33 \%$ positive stromal cells: $2=34-66 \%$ positive stromal cells; and $3=67-100 \%$ positive stromal cells. Then on the same fields the intensity of the signal was analyzed using the following scale: $0=$ no signal; $1=$ weak signal detected on high magnification ( $x 400)$; $2=$ moderate signal detected at medium magnification (x100); and $3=$ strong signal detected on low magnification $(x 40)$. At the end the percentage of positive cells was added to the intensity of the signal to reach the "staining index": 0=no signal; 1-2 low staining index (1); 3-4=moderate staining index (2); and 6-9=high staining index (3) $[5,7-8]$.

This counting method was repeated in the surrounding areas of benign prostatic tissue and the initial field chosen for analysis was the field with the most intense red color in the histochemical stain Trichrome Masson. Normal fibro muscular stroma of the prostate stains red, meaning that there is no reactive stroma that stains blue and the staining score is 0 .

The results between the prostatic cancer stroma and stroma of the surrounding benign prostatic tissue were 
correlated. Also additional pathological parameters like tumor grade (Gleason grade) and tumor extension or tumor stage (pT category) that were retrieved from the patohistology reports were correlated with the stromal changes in the prostatic carcinoma areas.

Statistical analysis was performed using chi square test and, for correlation between parameters, Spearman coefficient rank correlation test was used. The levels of statistical significance were set at $p<0,05$.

\section{Results}

Trichrome Masson histochemical stain showed most frequent staining intensity score 2 in the stroma of the prostatic cancer $(44,28 \%)$ and most frequent staining intensity with score 1 in the stroma of the surrounding benign prostatic hyperplasia (70\%). The tested difference in the staining intensity between the stromal cells of prostatic carcinoma and benign prostatic hyperplasia is statistically significant $($ Chi-square $=37,71 \mathrm{df}=1 \mathrm{p}<0,001)($ Table 1$)$.

Table 1. Staining intensity of Trichrome Masson in stromal cells of prostatic carcinoma and benign prostatic hyperplasia

\begin{tabular}{lcc}
\hline Staining intensity & $\begin{array}{c}\text { Trichome- } \\
\text { carcinoma N(\%) }\end{array}$ & $\begin{array}{c}\text { Trichrome- } \\
\text { BPH N(\%) }\end{array}$ \\
\hline 0 & 0 & 0 \\
1 & $11(15,71 \%)$ & $49(70,0 \%)$ \\
2 & $31(44,28 \%)$ & $20(28,57 \%)$ \\
3 & $28(40,0 \%)$ & $1(1,43 \%)$ \\
1 and $2-$ low & $42(59,99 \%)$ & $69(98,57 \%)$ \\
$3-$ moderate & $28(40,0 \%)$ & $1(1,43 \%)$ \\
\hline Tested differences & Chi-square $=31,71 \mathrm{df}=1 \mathrm{p}<0,001$
\end{tabular}

Vimentin antibody showed most frequent staining index of 3 in the stroma of the prostatic carcinoma $(48,57 \%)$ and in the surrounding benign prostatic tissue the most frequent staining index was $1(67,14 \%)$. Vimentin antibody showed significantly (Chi-square $=45,55 \mathrm{df}=1 \mathrm{p}<0,001$ ) greater expression in the stroma of the prostatic carcinoma compared to the stroma of benign prostatic hyperplasia (Table 2).
Table 2. Stainng index of Vimentin antibody in stromal cells of prostatic carcinoma and stromal cells of benign prostatic hyperplasia

\begin{tabular}{lcc}
\hline Staining index & $\begin{array}{c}\text { Vimentin- } \\
\text { carcinoma (N\%) }\end{array}$ & $\begin{array}{c}\text { Vimentin- } \\
\text { BPH N(\%) }\end{array}$ \\
\hline 0 & 0 & 0 \\
1 & $8(11,43 \%)$ & $47(67,14 \%)$ \\
2 & $28(40,0 \%)$ & $22(31,43 \%)$ \\
3 & $34(48,57 \%)$ & $1(1,43 \%)$ \\
1 and 2- low & $36(51,43 \%)$ & $69(98,57 \%)$ \\
3 - moderate & $34(48,57 \%)$ & $1(1,43 \%)$ \\
\hline Tested differences & Chi-square $=45,55 \mathrm{df}=1 \mathrm{p}<0,001$
\end{tabular}

Desmin antibody in the stroma of prostatic cancer showed most frequent staining index of $2(60 \%)$ while in the stroma of the surrounding benign prostatic hyperplasia all the cases showed staining index of $3(100 \%)$. The differences in staining index between the prostatic cancer stromal calls and stromal cells of the surrounding benign prostatic tissue is significant (Chi square $=117,89$ $\mathrm{df}=1 \mathrm{p}<0,001)($ Table 3$)$.

Table 3. Stainng index of Desmin antibody in stromal cells of prostatic carcinoma and stromal cells of benign prostatic hyperplasia

\begin{tabular}{lcc}
\hline Staining index & $\begin{array}{c}\text { Desmin- } \\
\text { carcinoma N(\%) }\end{array}$ & $\begin{array}{c}\text { Desmin- } \\
\text { BPH N(\%) }\end{array}$ \\
\hline 0 & 0 & 0 \\
1 & $22(31,43 \%)$ & 0 \\
2 & $42(60,0 \%)$ & 0 \\
3 & $6(8,57 \%)$ & $70(100 \%)$ \\
1 and 2 & $64(91,43 \%)$ & 0 \\
3 & $6(8,57 \%)$ & $70(100 \%)$ \\
\hline Tested differences & Chi-square $=117,89 \mathrm{df}=1 \mathrm{p}<0,001$
\end{tabular}

Trichrome Masson stain showed positive correlation with Vimentin expression $(\mathrm{R}=0,68 \mathrm{p}<0,001)$, Gleason score $(R=0,27 \mathrm{p}=0,023)$ and tumor stage $(\mathrm{R}=0,24 \mathrm{p}=0,049)$ and inverse correlation with Desmin expression $(\mathrm{R}=-0,28$ $\mathrm{p}=0,023)$. This means that the intensity of blue staining grows with the intensity of Vimentin expression and the increase of tumor grade and tumor stage (Table 4).

Table 4. Correlations of Trichrome Masson, Vimentin and Desmin in stromal cells of prostatic carcinoma with each other and with tumor grade and tumor stage

\begin{tabular}{lcc}
\hline Trichrome with & Spearman Rank R & p-value \\
\hline Vimentin & $\mathrm{R}=0,68$ & $\mathrm{t}=7,67 \mathrm{p}<0,001^{* *}$ \\
Desmin & $\mathrm{R}=-0,28$ & $\mathrm{t}=2,39 \mathrm{p}=0,02^{*}$ \\
Tumor grade (Gleason) & $\mathrm{R}=0,27$ & $\mathrm{t}=2,32 \mathrm{p}=0,023^{*}$ \\
Tumor stage (T category) & $\mathrm{R}=0,24$ & $\mathrm{t}=1,99 \mathrm{p}=0,049$ \\
Vimentin with & Spearman Rank R & $\mathbf{p}$-value \\
Trichrome & $\mathrm{R}=0,68$ & $\mathrm{t}=7,67 \mathrm{p}<0,001^{* *}$ \\
Desmin & $\mathrm{R}=-0,15$ & $\mathrm{t}=1,28 \mathrm{p}=0,2 \mathrm{NS}$ \\
Tumor grade (Gleason) & $\mathrm{R}=0,35$ & $\mathrm{t}=3,03 \mathrm{p}=0,003^{* *}$ \\
Tumor stage (T category) & $\mathrm{R}=0,28$ & $\mathrm{t}=2,4 \mathrm{p}=0,019^{*}$ \\
Desmin with & Spearman Rank R & $\mathbf{p}$-value \\
Trichrome & $\mathrm{R}=-0,28$ & $\mathrm{t}=2,39 \mathrm{p}=0,02^{*}$ \\
Vimentin & $\mathrm{R}=0,15$ & $\mathrm{t}=1,28 \mathrm{p}=0,2 \mathrm{NS}$ \\
Tumor grade (Gleason) & $\mathrm{R}=-0,25$ & $\mathrm{t}=2,14 \mathrm{p}=0,035^{*}$ \\
Tumor stage (T category) & $\mathrm{R}=-0,2$ & $\mathrm{t}=1,7 \mathrm{p}=0,095 \mathrm{NS}$ \\
\hline
\end{tabular}

$* \mathrm{p}<0,05 \quad * * \mathrm{p}<0,01 \quad$ NS-not significant 
Vimentin expression in stromal cells of prostatic carcinoma shows significant correlation with Trichome Masson staining intensity $(\mathrm{R}=0,68 \mathrm{p}<0,001)$, Gleason score $(R=0,35 \mathrm{p}=0,003)$ and tumor stage $(R=0,28$ $\mathrm{p}=0,019)$. These results mean that Vimentin expression increases in stromal cells of prostatic carcinoma together with the increase of tumor grade and tumor stage (Table 4). Desmin expression showed significant inverse correlation with Trichrome Masson staining intensity $(\mathrm{R}=-$ $0.28 \mathrm{p}=0,02)$ and Gleason score $(\mathrm{R}=-0,25 \mathrm{p}=0,035)$. The correlation of Desmin expression with tumor stage was not significant (Table 4).

\section{Discussion}

The somatic theory states that genetic mutations are the basis of the process of carcnogenesis. Mutations are direct cause of sporadic cancers that encompass $95 \%$ of human malignant neoplasms. However novel ideas question this theory [9-12]. In spite of aggressive attempts in laboratories worldwide this theory of somatic mutations can not be firmly established. Growing evidence support a role of tissue interactions in carcinogenesis [13-15]. The role of oncogene/suppressor gene concept as last incarnation of somatic theory is questioned many times [13-14]. Tissue related concepts were introduced as corrections in the current theory of somatic mutations rather then discarding completely this somatic theory [16-17]. As a complement to mutations, the final resolution of malignant neoplastic phenotype had to accommodate the role of stromal-epithelial interaction, and a new hybrid theory for carcinogenesis emerged, that incorporated elements of theory of somatic mutations and the role of stromal-epithelial interactions in the process of carcinogenesis [18]. This hybrid theory is the epigenetic theory of carcinogenesis that implies tissue based phenomena in modifications of epigenetic gene expression. Alternative theories to somatic mutation emerged that state carcinogenesis as a problem of normal histogenesis and tissue repair [15]. This new approach assumes that proliferation is the basic state of cels [19]. This view is diametrically opposite to the theory of somatic mutations where quiescence is the basic state of cells in multicellular organisms. This alternative theory, that incorporates the tissues as target of carcinogenesis, and proliferation as the basic state of cells is called tissue organization field theory [20].

In practice, stromal changes are currently thoroughly investigated in order to relate those changes with tumor grade and tumor stage. Authors design various methods of quantification of these stromal changes [5,7-8]. These studies have shown that grading stromal changes can predict tumor aggressiveness and tumor recurrence. The value of the well established Gleason grading system, that analyzes the morphology of the epithelial malignant cells, is unquestionable. However assessment of stromal changes as well, could serve as valuable comple- ment to Gleason grading system. When comparing patients with identical Gleason grade the intensity of Vimentin expression could identify patients with higher risk of disease recurrence [7]. Also Trichrome Masson histochemical stain can be used in everyday practice in interpretation of difficult cases of prostatic carcinoma in needle core biopsies when the diagnostic epithelial malignant cells are few in number to render a correct diagnosis [8].

Our study showed significant correlation of the intensity of Trichrome Masson stain with tumor grade (Gleason grade) that measures tumor aggressiveness and tumor stage ( $\mathrm{T}$ category) that measures tumor extent, tumor volume or tumor spread. Also, there was a significant correlation of the expression of Vimentin antibody with tumor grade and tumor stage. Desmin expression showed significant inverse correlation only with tumor grade. Our study analyzed specimens from radical prostatectomies where the whole prostate was sampled but other authors used the same methods on needle core biopsies [7,21-22]. This field of research is relatively new and additional studies like this are required to resolve several issues concerning the interpretation of the findings, Several methods of quantification of stromal changes have been proposed and a unifying concept has to emerge, concerning the issue of tumor heterogeneity, tumor volume, finding of adequate fields of assessment of stromal changes and so on.

\section{Conclusion}

Assessment of stromal changes in prostatic carcinoma, in the future, might serve as additional diagnostic and prognostic tool in everyday practice. Further basic research studies might elucidate the changes on molecular level, concerning stromal cells in malignant prostatic carcinoma, and mutation of stromal cells could be target for novel monoclonal gene therapy.

Conflict of interest statement. None declared.

\section{References}

1. Grossfeld GD, Hayward SW, Tisty TD, Cunha GR. The role of stroma in prostatic carcinogenesis. Endocr Relat Cancer 1988; 5: 253-270.

2. Ronnov-Jessen L, Petersen OW, Bissell MJ. Cellular changes involved in conversion of normal to malignant breast: importance of the stromal reaction. Physiol Rev 1996; 76: 69-125.

3. Cunha GR, Hayward SW, Dahiya R, Foster BA. Smooth muscle-epithelial interactions in normal and neoplastic prostatic development. Acta Anat (Basel) 1996; 155: 63-72.

4. Hayward SW, Rosen MA, Cunha GR. Stromal-epithelial interactions in the normal and neoplastic prostate. Br J Urol 1997; 79(Suppl 2): 18-26.

5. Tuxhorn JA, Ayala GE, Smith MJ, et al. Reactive stroma in human prostate cancer: induction of myofibroblast phenotype and extracellular matrix remodeling. Clin Cancer Res 2002; 8(9): 2912-223. 
6. Sappino AP, Schurch W, Gabbiani G. Differentiation repertoire of fibroblastic cells: expression of cytoskeletal proteins as marker of phenotypic modulatons. Lab Investig 1990; 63: 144-161.

7. Tomas D, Spajic B, Milosevic M, et al. Intensity of stromal changes predicts biochemical recurrence-free survival in prostatic carcinoma. Scand J Urol Nephrol 2010; 44(5): 284-290.

8. Tomas D, Kruslin B. The potential value of (Myo)fibroblastic stromal reaction in the diagnosis of prostatic adenocarcinoma. Prostate 2004; 61(4): 324-331.

9. Hahn WC, Weinberg RA. Rules for making human tumor cells. N Engl J Med 2002; 347: 1593-604.

10. Soto AM, Sonnenschein C. The somatic mutation theory of cancer: Growing problems with the paradigm? Bioessays 2004; 26: 1097-1107.

11. Van Regenmortel MH. Biological complexity emerges from the ashes of genetic reductionism. J Mol Recognit 2004; 17: $145-148$.

12. Fukino K, Shen L, Matsumoto S, et al. Combined total genome loss of heterozygosity scan of breast cancer stroma and epithelium reveals multiplicity of stromal targets. Cancer Res 2004; 64: 7231-7236.

13. Olumi AF, Grossfeld GD, Hayward SW, et al. Carcinomaassociated fibroblasts direct tumor progression of initiated human prostatic epithelium. Cancer Res 1999; 59: 5002-5011.
14. Barcellos-Hoff MH, Ravani SA. Irradiated mammary gland stroma promotes the expression of tumorigenic potential by unirradiated epithelial cells. Cancer Res 2000; 60: 1254-1260.

15. Maffini MV, Soto AM, Calabro JM, et al. The stroma as a crucial target in rat mammary gland carcinogenesis. $J$ Cell Sci 2004; 117: 1495-1502.

16. Weinstein IB. Cancer. Addiction to oncogenes-the Achilles heal of cancer. Science 2002; 297: 63-64.

17. Sonnenschein C, Soto AM. Somatic mutation theory of carcinogenesis: why it should be dropped and replaced. $\mathrm{Mol}$ Carcinog 2000; 29: 205-211.

18. Bissell MJ, Radisky D. Putting tumours in context. Nat Rev Cancer 2001; 1: 46-54.

19. Maffini MV, Geck P, Powell CE, et al. Mechanism of androgen action on cell proliferation: AS3 protein as a mediator of proliferative arrest in the rat prostate. Endocrinology 2002; 143: 2708-2714

20. Sonnenschein C, Soto AM. Are times a' changin' in carcinogenesis? Endocrinology 2005; 146(1): 11-12.

21. Ayala G, Tuxhorn JA, Wheeler TM, et al. Reactive stroma as a predictor of biochemical-free recurrence in prostate cancer. Clin Cancer Res 2003; 9: 4792-4801.

22. Yanagisawa N, Li R, Rowley D, et al. Stromogenic prostatic carcinoma pattern (carcinomas with reactive stromal grade 3 ) in needle biopsies predicts biochemical recurrence-free survival in patients after radical prostatectomy. Hum Pathol 2007; 38: 1611-1620. 